\title{
Designing of 3MW Floating Photovoltaic Power System and its Benefits over Other PV Technologies
}

\author{
H.D.Milan Ravinath Perera ${ }^{1}$ \\ Individual Researcher (MSc,BEng(Hons),MIET,MIEEE) ${ }^{1}$ \\ ${ }^{1}$ Sustainable Energy Engineering \\ Mahara, Colombo \\ Sri Lanka
}

\begin{abstract}
Renewable energy power generation should be more specific of what type of energy does it need to be used to cater to the demand of consumers. This should be more reliable, economical and efficient with making maximum benefit towards the environment. This research is based on Floating Photovoltaic Technology and the author has designed a 3MW FPV system, which it was then compared with other PV technologies developed around the world, and it was mainly analyzed by simulation results obtained by PVSyst software interface and using actual climatic data from NASA. Therefore, it was proved that the author designed the system generates more power compared to other methods and it gives more environmental benefits compared to other topologies. This system will give solutions to the problem of a negative impact on the environment with PV energy as it only uses water surface to integrate the $P V$.
\end{abstract}

Key Words: Floating Photovoltaic, Anchoring, Cooling effect, Evaporation.

\section{INTRODUCTION}

According to the facts of environmental pollution and global warming due to many fossil powered electricity generation systems, it was required to find out an alternative solution to mitigate these problems and revers the effect on environment. Therefore, many engineers around the world started to develop renewable energy power generation systems such as wind power, solar power, biomass and tidal energy, and this era is the transition period of fossil energy to renewable energy in the entire world. Photovoltaic power technology is one of the world most prominent renewable energy power generation method, and due to rapid growth of research and development in solar power industry, the cost per kW dropped nearly by $60 \%$ as at 2019 , and this expected to fall further below in future. Although ground mounted and roof mounted solar power systems are widely used, this paper is written based on Floating Photovoltaic (FPV) power generation method which its main research aim and objective is to designing the FPV system in comparative way to generate maximum generation with most economical and feasible process among other PV technologies with addition benefit towards the environment.

\subsection{Problem Identification}

Negative impact on environmental with photovoltaic energy -

The fossil fuel power generation produces large number of $\mathrm{CO}_{2}$ to the environment, and as for the scientific researches, the renewable energy power generation sources will not produce any $\mathrm{CO}_{2}$ to the environment during power generation. Thus, solar power generation is prominent in the community and it has addressed the $\mathrm{CO}_{2}$ problem, but it has created new problems with large number of land requirement and excessive water usage during manufacturing, and cleaning of PV. Ground mounted large scale PV systems required large acres of land and a typical 3MW ground mounted PV system will acquire approximately 15 20 acres of land, which the land to energy generated ratio is higher compared to other power generation techniques[1]. Therefore, when implementing solar power systems, it should be more focus on not only to reduce $\mathrm{CO}_{2}$ emission but not to create alternative drawbacks after implementation.

\section{LITERATURE REVIEW}

The term photovoltaic means that the material or device can convert the energy contain in photons of light into an electrical voltage and current. The first crystalline silicon PV was found in 1940's and 1950's by Jan Czochralski, a Polish scientist. This technology was then used in 1958 , by T. Mandelkorn, U.S. Signal Corps Laboratories, with the creation of n-on-p silicon solar 
cells, which are more resistant to radiation damage and are better suited for space applications and thus, Vanguard I, the first solar powered satellite, was launched with a $0.1 \mathrm{~W}, 100 \mathrm{~cm}^{2}$ solar panel. This technology was then used to create ground powering applications during 1980's and rapid development of PV technology has created less cost higher efficiency solar cells currently. The $90 \%$ of worldwide used high efficiency solar panel cell type is mono-crystalline silicon and it has the highest energy conversion rate of $25 \%$ maximum under standard test conditions (STC), when other poly-crystalline cells have reached only 15 $18 \%$ under STC. Therefore, mono-crystalline solar cells will be connecting in series to create a complete solar panel which will be using for solar power generation as shown in standard equivalent circuit of solar cell connection below.

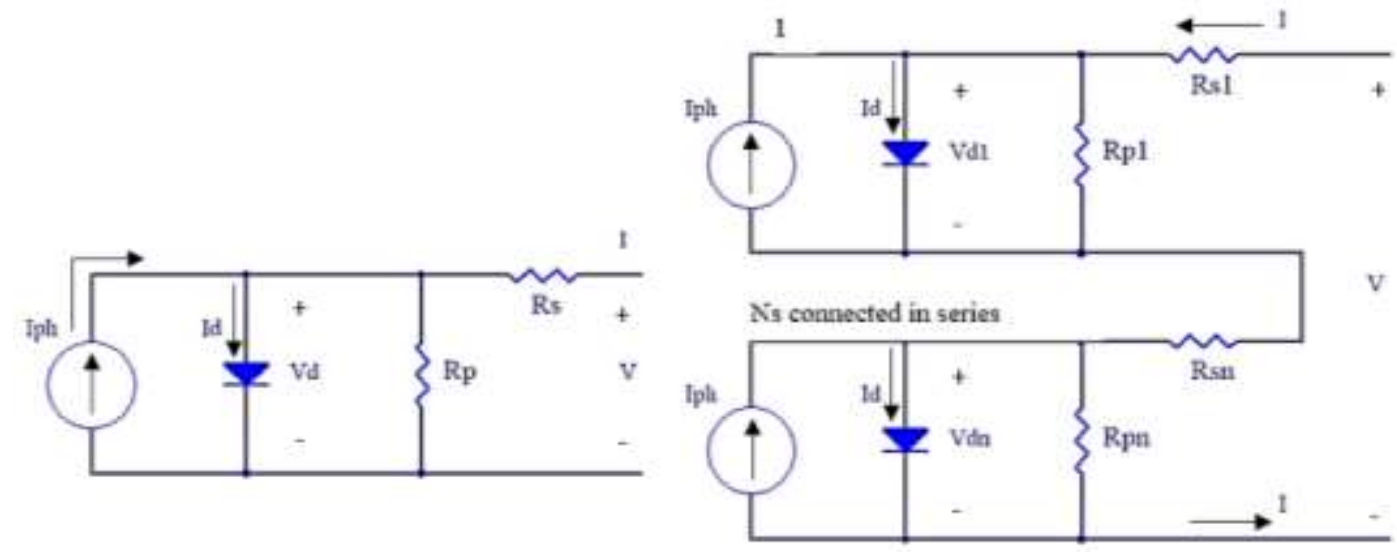

Fig. 1 PV cell equivalent circuit

According to the equivalent circuit, the equation for single sell can be written as follows [2],

$$
I=I_{p h}-I_{0}\left[\exp \left(\frac{V+R_{S}}{\text { A. Ns. } V_{T}}\right)-1\right]-\frac{V+R_{S}}{R_{p}}
$$

$\mathrm{I}_{\mathrm{D}}$ is based on Shockley equation for an ideal diode, I is maximum generated current from the PV cell, $\mathrm{I}_{\mathrm{ph}}$ is light dependent current, $\mathrm{I}_{0}$ is diode reverse saturation current, $\mathrm{R}_{\mathrm{S}}$ is Series resistance, $\mathrm{R}_{\mathrm{P}}$ is shunt resistance, $A$ is the diode ideality factor that depend on recombination factor and $\mathrm{V}_{\mathrm{T}}$ is thermal voltage $(25.9 \mathrm{mV}$ at $300 \mathrm{~K})$. With Ns number of cells connect in series, the equation can be rewrite as[3],

$$
\begin{gathered}
\mathrm{I}_{\mathrm{M}}=\mathrm{I}_{\mathrm{L}}-\mathrm{I}_{0}\left[\exp \left(\frac{\mathrm{V}+\mathrm{I}_{\mathrm{M}} \mathrm{NR}_{\mathrm{S}}}{\eta N s V_{\mathrm{T}}}\right)-1\right]-\frac{\mathrm{V}+\mathrm{I}_{\mathrm{M}} \mathrm{NsR}_{\mathrm{S}}}{\mathrm{NsR}_{\mathrm{p}}} \\
\mathrm{V}_{\mathrm{T}}=\mathrm{K} \cdot \mathrm{T}_{\mathrm{C}} / \mathrm{q}
\end{gathered}
$$

$\mathrm{K}$ is Boltzmann constant of $1.381 \times 10^{-23} \mathrm{~J} / \mathrm{K}$, and ' $\mathrm{q}$ ' is electron charge of $1.602 \times 10-19 \mathrm{C}$. All the terms for $\mathrm{V}$ divided in equation under exponential function will inversely proportional to cell temperature and vary with conditions such as irradiation and temperature. Therefore, it can be re-write as " $a$ " and thermal voltage where ' $a$ ' is modified ideality factor.

$$
\mathrm{a}=\frac{\mathrm{Ns} \cdot \mathrm{A} \cdot \mathrm{K} \cdot \mathrm{Tc}}{\mathrm{q}}=\mathrm{Ns} \cdot \mathrm{A} \cdot \mathrm{V}_{\mathrm{T}}
$$

Therefore, the output current of a module containing Ns cells in series will be denote as,

$$
I=I_{p h}-I_{o}\left[\exp \left(\frac{V+I . R s}{a}\right)-1\right]-\frac{V+R s . I}{R p}
$$

Iph depend on both irradiance and temperature, therefore,

$$
\mathrm{I}_{\mathrm{ph}}=\frac{\mathrm{G}}{\mathrm{G}_{\mathrm{ref}}}\left(\mathrm{I}_{\mathrm{ph}, \mathrm{ref}}+\mu_{\mathrm{sc}} \cdot \Delta \mathrm{T}\right)
$$

$\mathrm{G}$ and Gref will be irradiance and irradiance at STC $(1000 \mathrm{~W} / \mathrm{m} 2)$ respectively. $\mu_{s c}$ is known as coefficient temperature of short circuit current $(\mathrm{A} / \mathrm{K})$ and $\Delta T=\mathrm{Tc}-\mathrm{Tc}$,ref (Kelvin) where Tc,ref is the cell temperature at STC $(25+273 \mathrm{~K})$. 
To determine Io, following relationships should be considered, Current at short circuit ( $\mathrm{V}=0$, I=Isc,ref), voltage (Vmp,ref), current (Imp,ref) at maximum Power. Therefore, it can obtain [4],

$$
\begin{gathered}
I_{\text {sc,ref }}=I_{\text {ph,ref }}-I_{0, \text { ref }}\left[\exp \left(\frac{I_{\text {sc,ref }} \text { Rs }}{a_{\text {ref }}}\right)-1\right] \\
0=I_{\text {ph,ref }}-I_{0, \text { ref }}\left[\exp \left(\frac{V o c}{a_{\text {ref }}}\right)-1\right] \\
I_{\text {pm,ref }}=I_{\text {ph,ref }}-I_{0, \text { ref }}\left[\exp \left(\frac{V p m, \text { ref }+ \text { Ipm, ref. Rs }}{a_{\text {ref }}}\right)-1\right]
\end{gathered}
$$

Thus,

$$
\begin{gathered}
I_{0, \text { ref }}=I_{\text {sc,ref }} \cdot \exp \left(\frac{- \text { Voc, ref }}{a}\right) \\
\text { Io }=D^{D T c} c^{3} \exp \left(\frac{-q \varepsilon G}{A \cdot K}\right)
\end{gathered}
$$

Where, Io is the revers saturation current. Therefore, with the usage of above equations, it can be designed a photovoltaic panel as per the requirement.

In addressing FPV, two third of world is covered with water, and according to the solar power technology there are several classifications of PV installations, such as [5]

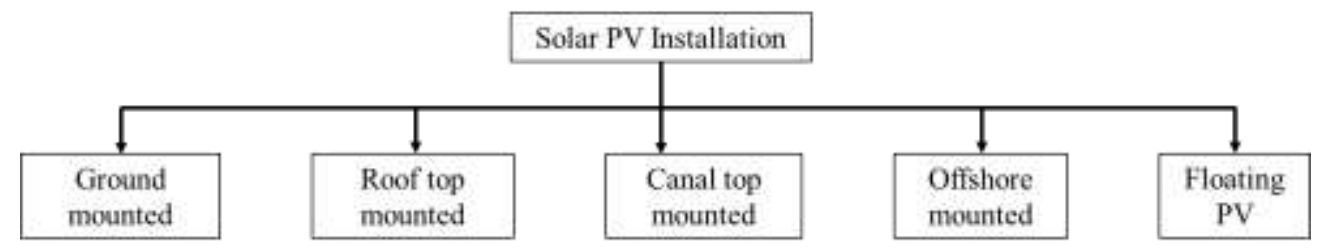

Off-shore concepts are developed currently to enhance the opportunities to harness renewable energy for power generation like Offshore wind, tidal energy, wave energy and in recent years solar power systems developed in a vast scale in such that it could install the PV panels on top of the water bodies which named floating solar PV technology to create more benefits towards generation and society[6]. A total of 4,400 GWp of floating solar power capacity can be installed and 6,270 TWh of generation can be covered globally with just covering $25 \%$ of the surfaces of estimated water bodies. The FPV can be installed in water bodies such as oceans, lakes, lagoons, reservoirs, irrigation ponds, wastewater treatment plants, wineries, fish farms, dams and canals etc. With this concept, many countries introduced the FPV technology as an alternative energy source to produce electricity. The below table express the FPV installed countries around the world [5].

Table 1. FPV installed capacity globally.

\begin{tabular}{cc}
\hline Country & Installed FPV MW capacity \\
\hline China & 376.5 \\
\hline Japan & 22.66 \\
\hline United Kingdom & 9.33 \\
\hline South Korea & 6 \\
\hline Australia & 4 \\
\hline Italy & 0.77 \\
\hline United states & 0.67 \\
\hline Spain & 0.32 \\
\hline France & 0.12 \\
\hline India & 0.06
\end{tabular}

Compared to all countries around the world, China has developed more FPV systems during past years and it has the world largest FPV system with a $40 \mathrm{MW}$ installed capacity [7] 
Floating solar power system concept and technology was patented by American, Danish, French, Italian and Japanese nationals from the year of 2007. The concept outline is that the PV installed on a water surface with the use of a floating platform [8]. Due to effect of corrosion, FPV installation on salt concentrated water is not common in implementation. Thus, there have been different researches were done with the consideration of the FPV allocation. R. Cazzaniga, M. Rosa-Clot proposed a novel Floating tracking cooling concentrating (FTCC) system which was more efficient in comparison with conventional FPV systems, this was integrated with boost reflectors and a concentrators to harness maximum irradiation, thus increase the energy generation and improve the efficiency [9]. Trapani K, Millar proposed an offshore FPV design for Maltese Island and this feasibility study discussed the economic facts and the $\mathrm{CO} 2$ reduction with the implementation. According to this research, the thin-film PV integrated FPV technology has the lower discounted cost, rather than current electricity generation methods, and this helps for saving cost and CO2 significantly [10]. C. Ferrer-Gisbert did a prototype based and real experiment implementation covering 7\% of an agriculture reservoir which resulted in water evaporation reduction, also, the economic analysis explained that this system of $100 \mathrm{kWp}$ of FPV is $30 \%$ higher than the cost of conventional PV system with the profitability index (PI) of 9.86\%, Net Present Value (NPV) value of 5\% and Internal rate of return (IRR) of 12.65\% [11]. Choi and Lee developed a novel tracking based FPV system with consideration of life span of the system by considering material properties and several practical experiments and simulations. Structural properties due to wind loads were tested using wind tunnel experiments. Thus, it did not discussed the financial modeling for the $100 \mathrm{~kW}$ system which expected to be higher initial investment as it include many mechanical controlling strategies [12]. C. Solanki and G. Nagababu proposed to create offshore FPV system assessing the mean global horizontal radiation and the power production in different coasts of India. Results show that average mean GHI and the estimated solar power generation in study area are $5.49 \mathrm{kWh} / \mathrm{m} 2$ per day and $9372 \mathrm{TWh}$ per day respectively [13]. M. Rosa-Clot explained the important of installing FPV on a wastewater basin and describes in detail about the water evaporation reduction and power generation gain using this system which influenced by the latitude and weather conditions. As per the results, it estimates that between 15,000 and 25,000 cubic meter of water saved for each MWp installed and the energy yield is increased up to 10\% due to cooling effect from water surface [14]. R. Cazzaniga and M. Cicu introduced a system of compressed air energy storage integrated with FPV which suitable for both fixed and tracking systems. According to this method, the floating PV supplies electric energy to the grid or to the air compressor through inverter. The air compressor will increase the pressure in pipes from $0.1 \mathrm{MPa}$ up to $20 \mathrm{MPa}$, then the stored air can be used to produce energy through a turbine. Thus, the pontoon's cost is only slightly increased and the system looks simple from the structural point of view [15]. A case study was done by C. Study and S. Kei to observe the performance of sea FPV and diesel hybrid power system in Southeast Moluccas, Indonesia. The battery pack of 3 separate sets were installed to reduce the fluctuation of the output power generated by DG. The battery which used in this system have a Depth of Discharge (DOD) value of $70 \%$ and battery cycle life is 3360 times and the battery replacement will be required every 13 years. According to the financial analysis, the LCOE of FPV system with hybrid diesel is expensive with an IRR rate of $11.65 \%$ and PI ratio of 1.016 compared to conventional PV system, but it is expected to fall rapidly with the development of battery and PV systems [16]. The other hybrid method was discussed by L. E. Teixeira and J. Caux, considering FPV/hydropower hybrid system. The location was selected as dam of Val de Serra, in southern Brazil. As per the design, a hydroelectric plant with a capacity of $227 \mathrm{~kW}$ can operate with 60kW FPV hybrid system. The generation of FPV and hydropower was simulated by Homer software and explained the load demand matching using both systems according to the potential. The reduction of evaporation of water helps to preserve water in the reservoir which help the hydropower turbines to operate for a longer period of time. It was observed $30 \%$ increment of cost when implementing hybrid system compared to conventional energy systems [17].

The FPV architecture includes extra components compared to conventional PV integrations due to its special requirement of floating on top of the water surface. There are three main parameters are essential to evaluate a water body, those are, the area of the water body, the shape, the bottom and banks type. For technical reasons, the PV plant will have either Rectangular, Square or Stairs shape. Each shape will affect on cost of implementation and complexity. Under designing a FPV on a pond, it is not expected to put floats near the bank. It needs to preserve a certain distance between the banks and the island sides. This distance takes the anchoring system and the movement of the island into account. This is to make sure that if the water body empties, the solar island will remain on the flat area at the bottom and will not be twisted by some relief. The Floating platforms, PV modules and anchoring components of FPV are described below accordingly with refer to the above details[18],

The floating platform is known as pontoons which capable of floating on water surface with guaranteed buoyancy and stability of the electricity-generating system. These are designed to hold one or two PV panels together with a specific inclination. The aisle float as the vice float connects the main floats together, using a flexible connection between the floating bodies [19]. The float is made of blow molding by modified high density polyethylene, promised service life more than 25 years. 
International Journal of Advances in Scientific Research and Engineering (ijasre), Vol 6 (4), April -2020

Table 2. Main components of floating platform

\begin{tabular}{|l|l|}
\hline \multicolumn{1}{|c|}{ Component identity } & \multicolumn{1}{c|}{ Description } \\
\hline Main float supporting the PV module & HDPE material with $12^{0}$ inclination angle \\
\hline Secondary float for maintenance/Buoyancy & HDPE material, non-slipping surface \\
\hline Connection Pin & Fiberglass + PP material, Certification NFT58000 \\
\hline Rail to attach the PV module to the floats & Aluminum or fiberglass + PP rail, ISO 3302-1/1996 \\
\hline Standard framed 60 or 72 cell PV module & $\begin{array}{l}\text { Dimensions depend on the PV panel characteristics } \\
60 \text { cell }: \mathrm{L} * \mathrm{~W}(1670 \mathrm{~mm} * 991 \mathrm{~mm}) \\
72 \text { cell }: \mathrm{L} * \mathrm{~W}(1975 \mathrm{~mm} * 991 \mathrm{~mm})\end{array}$ \\
\hline
\end{tabular}

The floating material is food grade HDPE and its non-toxic and tasteless with anti-oxidation and anti-aging system. According to the regulations and standards, these floating structures conforms to ROHS and REACH system protection, and therefore, it is environmentally friendly and harmless [19]. As per the current development, the PV modules that used in FPV will be either mono-crystalline, polycrystalline or thin-film. Most widely used is mono-crystalline PV since it has the highest efficiency in the PV industry. The variety of power capacity of PV depend on the number of cells include in the PV panel either 60 or 72 , currently, industry most preferred to use PV panels which has power rating more than $250 \mathrm{Wp}$ (60cell) with maximum available PV power capacity of $380 \mathrm{Wp}$ (72 cell) [20]. These PV panels undergoes different testing procedures to ensure that it can perform up to the conformance, which standard 25 years performance warranty and 5 or 10 years manufacturing warranty with higher reliability [21].

To address the anchoring problem, it has used FPV structure with complex anchoring technology which was designed not to slide excessively on water body with waves and avoid hitting the shores under changes of water level variations. The anchoring system design is usually composed with; Aluminum spreader bars and the mooring system which help to connect the array with the island. This was designed considering the maximum water level variation at site and the chains will be used to adjust the lengths. Complete system will reduce the movement on the water surface and will withstand the heavy wind loads at site. Such, the FPV developers have been using strip type cable expander components to cater the maximum water level variation of $3 \mathrm{~m} \sim 5 \mathrm{~m}$, and if the variation is excessive, the component will be expensive, and it is still limited to a maximum variation. The below image explains the anchoring phenomena in FPV system,

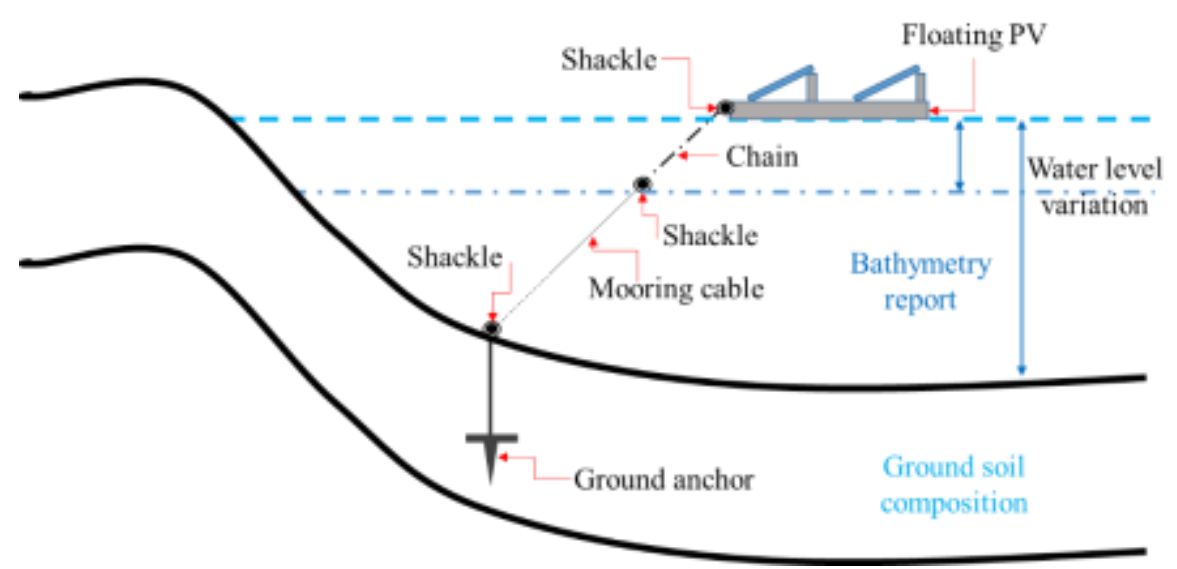

Fig. 2 Anchoring system in FPV.

The type of cable and the weight of anchor required when designing the anchoring system. This is determined according to the flow chart mentioned below. The total resistance $(\mathrm{R})$, is determined by combining the wind resistance (Ra), flow resistance (Rw), and effect of the shape of the structure (Rv) as given in equation [22].

$$
R=\sqrt{R_{a}^{2}+\left(R_{W}+R_{V}\right)^{2}}
$$




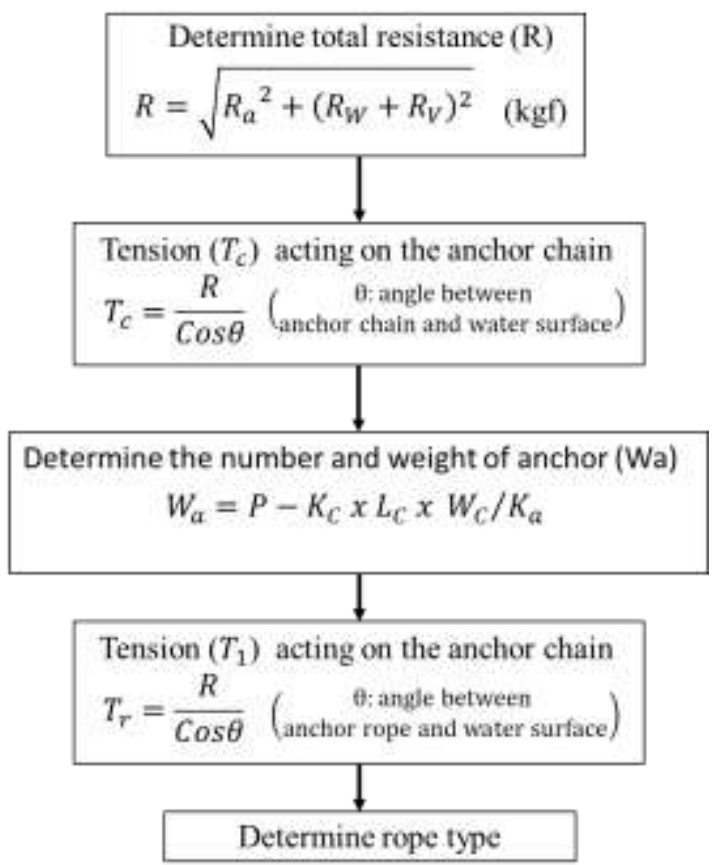

Under the operation of FPV, the electricity produced from the PV system will be drawn through cables to the land. Even though there are IP67/68 rated junction box's and cables, underwater cable laying is not common in FPV projects and it uses a cable duct on floating platforms to lay the cables. This is done regard to safety reasons and to avoid additional cost of water proof implementations [5]. The interconnections of FPV is more in common with conventional PV system and also the partial shading conditions on FPV is similar with conventional PV topology, and therefore, PV array interconnection topologies can be applied to FPV array to reduce the FPV power loss and mismatches.

As for the flow of literature review, initially it has discussed the FPV technology and its related technical designs. With these researches and other PV methods done across the world, it has created the below table, identifying its main pros and cons.

Table 3. Different PV systems main pros and cons categorized.

\begin{tabular}{|c|c|c|c|c|c|c|c|c|}
\hline $\begin{array}{l}\text { Research } \\
\text { Paper No. }\end{array}$ & $\begin{array}{l}\text { Power } \\
\text { Gain }\end{array}$ & $\begin{array}{c}\text { Cost } \\
\text { reduce }\end{array}$ & $\begin{array}{l}\text { Power } \\
\text { Drop }\end{array}$ & $\begin{array}{c}\text { Cost } \\
\text { Increase }\end{array}$ & $\begin{array}{l}\mathrm{CO} 2 \\
\text { Save }\end{array}$ & $\begin{array}{l}\text { Water } \\
\text { Save }\end{array}$ & $\begin{array}{c}\text { Land } \\
\text { benefit }\end{array}$ & $\begin{array}{c}\text { execution } \\
\text { ability }\end{array}$ \\
\hline [23] [24] & $\begin{array}{l}\checkmark \\
\text { Higher } \\
\text { than } \\
\text { ground } \\
\text { PV }\end{array}$ & $\begin{array}{l}\checkmark \\
\text { LCOE }\end{array}$ & $\begin{array}{c}\checkmark \\
\mathrm{Ta}\end{array}$ & $\checkmark$ & $\checkmark$ & $x$ & 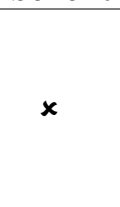 & - on \\
\hline [12] & $\checkmark$ & $x$ & $x$ & $\checkmark$ & $\checkmark$ & $\checkmark$ & $\checkmark$ & $x$ \\
\hline [14] & $\checkmark$ & $\begin{array}{c}\text { Less } \\
\text { compared } \\
\text { Tracking }\end{array}$ & $x$ & $\begin{array}{l}\text { Higher } \\
\text { referred } \\
\text { ground }\end{array}$ & $\checkmark$ & $\checkmark$ & $\checkmark$ & $\checkmark$ \\
\hline [9] & $\begin{array}{c}\checkmark \\
\text { Higher } \\
\text { than FPV }\end{array}$ & $x$ & $x$ & $\begin{array}{c}\checkmark \\
\text { Referred } \\
\text { FPV }\end{array}$ & $\checkmark$ & $\checkmark$ & $\checkmark$ & $x$ \\
\hline $\begin{array}{c}\text { Bifacial/FPV } \\
\text { Tracking }\end{array}$ & $\begin{array}{l}\checkmark \\
\text { higher }\end{array}$ & $x$ & $x$ & $\checkmark$ & $\checkmark$ & $\checkmark$ & $\checkmark$ & $x$ \\
\hline Bifacial/FPV & $\checkmark$ & $\begin{array}{c}\text { Less } \\
\text { compared } \\
\text { tracking }\end{array}$ & $x$ & $\begin{array}{l}\text { Higher } \\
\text { referred } \\
\text { ground }\end{array}$ & $\checkmark$ & $\checkmark$ & $\checkmark$ & $\checkmark$ \\
\hline $\begin{array}{c}\text { Mono-facial } \\
\text { Ground PV }\end{array}$ & $\begin{array}{l}\text { Less } \\
\text { Compare } \\
\text { d to FPV }\end{array}$ & $\begin{array}{c}\text { Less } \\
\text { compared } \\
\text { FPV }\end{array}$ & $\checkmark$ & $x$ & $\checkmark$ & $x$ & $x$ & $\checkmark$ \\
\hline $\begin{array}{l}\text { Mono-track } \\
\text { Ground PV }\end{array}$ & $\checkmark$ & $x$ & $\checkmark$ & $\checkmark$ & $\checkmark$ & $x$ & $x$ & $\checkmark$ \\
\hline
\end{tabular}




\section{METHODOLOGY \& SIMULATIONS}

The proposed project will be with the capacity of photovoltaic power generation of 3MW AC, approximately 3.564MW DC. The PV modules are to be fixed on the floats with optimum inclination. The PV modules are arranged south, the azimuth angle is $0^{\circ}$, the east-west spacing of PV modules is about $50 \mathrm{~mm}$, the north-south spacing of PV modules is about $450 \mathrm{~mm}$, to meet the requirements of non-blocking between the PV modules in the site area on Winter solstice 9: 00am 15: 00pm, and consider the maintenance channel. The capacity of each float matrices is about $0.75 \mathrm{MW}$ AC, approximately $0.891 \mathrm{MW}$ DC, east - west length is about $76 \mathrm{~m}$, width is about $97 \mathrm{~m}$, approximate a square. To facilitate maintenance installation, the group string inverters and AC combiner boxes are arranged at the center of the matrices. The technical parameters for the solar power system will be as follows,

Table 4. Technical data of FPV system.

\begin{tabular}{ll}
\hline \multicolumn{1}{c}{ Component } & \multicolumn{1}{c}{ Description } \\
\hline Shading or obstacles & Considered as no shading effect \\
\hline Orientation & South-East \\
\hline PV module model & Mon-250Wp 60 cell \\
\hline Number of PV modules in series & 13 \\
\hline Number of PV modules in parallel & 1097 strings \\
\hline Total PV modules in system & 14261 \\
\hline Array designed global power & $3565 \mathrm{kWp}$ \\
\hline Array operating characteristics at 50oC & Umpp - 352 V / Impp - 8970A \\
\hline Array area & $28,200 \mathrm{~m} 2$ \\
\hline Inverter capacity & $500 \mathrm{kWac}$ \\
\hline Operating voltage & $320-700 \mathrm{~V}$ \\
\hline Number of inverters & 6 \\
\hline Total power AC & $3000 \mathrm{~kW}$ \\
\hline DC/AC ratio & 1.19 \\
\hline
\end{tabular}

The below figure is the layout of the FPV floating schematic.

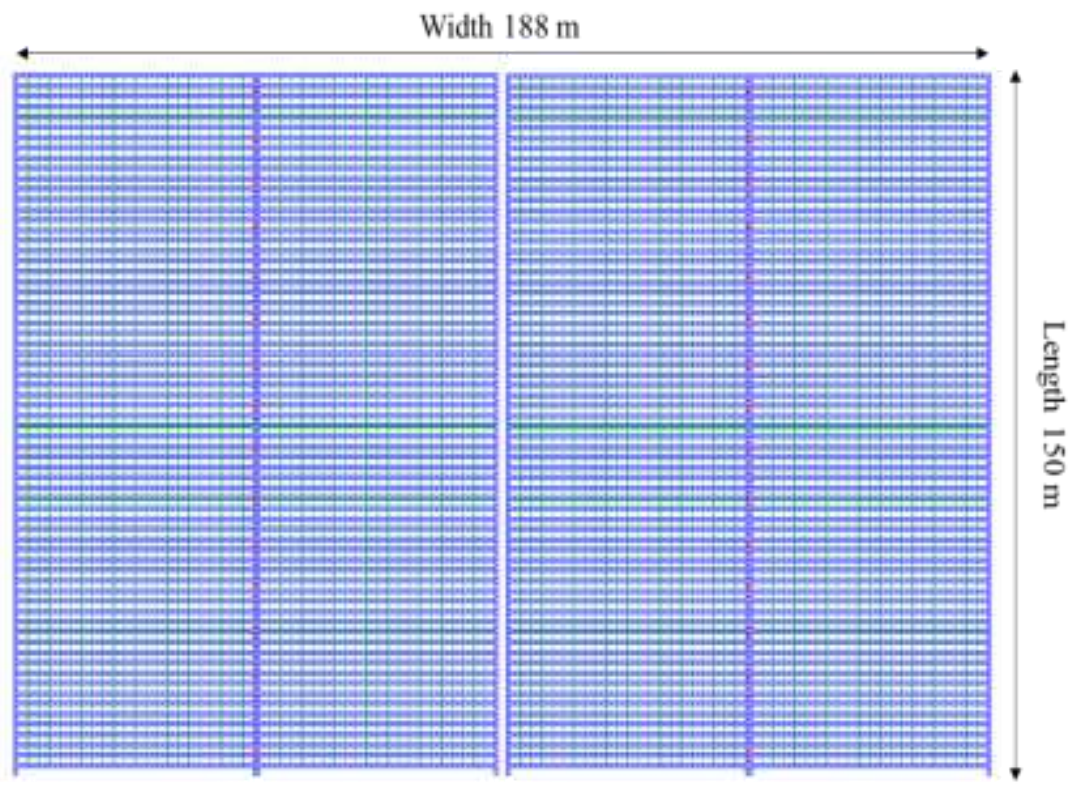

Fig. 3 FPV array layout (area-28,200m2).

The climate data will be defined as per the below table, 
International Journal of Advances in Scientific Research and Engineering (ijasre), Vol 6 (4), April -2020

Table 5. Environmental conditions

\begin{tabular}{cccc}
\hline Months & $\begin{array}{c}\text { Horizontal Global } \\
\text { irradiation } \\
\mathbf{k W h} / \mathbf{m}^{\mathbf{2}}\end{array}$ & $\begin{array}{c}\text { Temperature } \\
\mathbf{0} \mathbf{C}\end{array}$ & $\begin{array}{c}\text { Wind velocity } \\
\mathbf{~} / \mathbf{s}\end{array}$ \\
\hline January & 159.1 & 27.2 & 4.2 \\
\hline February & 156.4 & 26.9 & 3.0 \\
\hline March & 186.2 & 27.6 & 2.5 \\
\hline April & 174.6 & 27.3 & 2.3 \\
\hline May & 156.2 & 28.5 & 3.8 \\
\hline June & 154.7 & 27.5 & 4.4 \\
\hline July & 160.9 & 27.8 & 4.2 \\
\hline August & 163.7 & 27.7 & 4.4 \\
\hline September & 157.8 & 27.0 & 3.6 \\
\hline October & 161.2 & 26.9 & 2.8 \\
\hline November & 150.7 & 26.0 & 2.5 \\
\hline December & 133.8 & 25.4 & 3.5 \\
\hline
\end{tabular}

According to the research aim, different power generations were compared to observe its pros and cons, and therefore, the author used PVSyst6 software to simulate to justify the research materials and to observe the FPV design proposed in the thesis. The below table shows the methods and its 3MW power annual generation results in MWh according to the real meteorological data observed from NASA. The author designed system will be indicated by number (7) in the table. 'Mo' and 'bi' stands for Monofacial PV and Bifacial PV respectively.

Table 6. Types of PV generation methods and its annual generation and losses

\begin{tabular}{|c|c|c|c|c|c|c|}
\hline Mo/Ground & Mo/Ground & $\mathrm{Bi} / \mathrm{Ground}$ & Mo/FPV & $\mathrm{Bi} / \mathrm{FPV}$ & $\mathrm{Bi} / \mathrm{FPV}$ & $\mathrm{Mo} / \mathrm{FPV}$ \\
\hline Alb.20/Ta.27 & Alb.80/Ta.27 & Alb.80/Ta.27/ & Track/Alb.50 & Track/Alb.50 & Alb.50 & Alb.50 \\
\hline Tilt.30 & Tilt.30 & Tilt.30 & Ta.20/Tilt.15 & Ta.20/Tile. 15 & Та. 20 & Та. 20 \\
\hline (1) & (2) & (3) & (4) & (5) & $\begin{array}{l}\text { Tilt.15 } \\
(6)\end{array}$ & $\begin{array}{l}\text { Tilt.15 } \\
\text { (7) }\end{array}$ \\
\hline $4677 \mathrm{MW}$ & $4770 \mathrm{MW}$ & $5450 \mathrm{MW}$ & $5458 \mathrm{MW}$ & $5679 \mathrm{MW}$ & 5495 & 5315 \\
\hline Ta loss: $12.73 \%$ & Ta loss: $12.75 \%$ & Ta loss: $12.35 \%$ & Ta loss: $9.62 \%$ & Ta loss: $9.64 \%$ & $\begin{array}{c}\text { MW } \\
\text { Ta loss: } \\
9.64 \%\end{array}$ & $\begin{array}{c}\text { MW } \\
\text { Ta loss: } \\
9.62 \%\end{array}$ \\
\hline
\end{tabular}

The temperature reduction in FPV system will lead to generate more power compared with a ground mounted solar system and this will be one of the advantages. This will be achieved due to the cooling effect of the water body. To analyze this, the comparison of temperature variation with power generation is created. The Horizontal global irradiation, Horizontal diffuse irradiation, Global incident on Collector and Global effective irradiation was taken from NASA as done before. To observe the temperature effect, the author manually created the temperature profile at the given location as 20, 25, and 30 degrees of Celsius and used $500 \mathrm{~kW}$ inverter system.

Table. 7. Data from NASA at $7.17^{\circ} \mathrm{N}, \mathbf{7 9 . 8 8}^{\circ} \mathrm{E}$.

\begin{tabular}{ccccc}
\hline Month & GlobHor $\left(\mathbf{k W h} / \mathbf{m}^{\mathbf{2}}\right)$ & DiffHor $\left.\mathbf{( k W h} \mathbf{m}^{\mathbf{2}}\right)$ & GlobInc $\left.\mathbf{( k W h} / \mathbf{m}^{\mathbf{2}}\right)$ & GlobEff $\left(\mathbf{k W h} \mathbf{\mathbf { m } ^ { 2 }}\right)$ \\
\hline January & 159.1 & 74.20 & 181.4 & 176.6 \\
\hline February & 156.4 & 69.30 & 168.8 & 164.0 \\
\hline March & 186.2 & 77.00 & 181.8 & 175.8 \\
\hline April & 174.6 & 75.40 & 152.0 & 146.0 \\
\hline May & 156.2 & 86.80 & 125.1 & 11.2 \\
\hline June & 154.7 & 83.90 & 119.4 & 118.3 \\
\hline July & 160.9 & 75.00 & 124.4 & 132.2 \\
\hline August & 163.7 & 81.50 & 138.1 & 142.0 \\
\hline September & 157.8 & 76.30 & 147.3 & 163.0 \\
\hline October & 161.2 & 69.70 & 167.6 & 164.5 \\
\hline November & 150.7 & 68.50 & 168.7 & 151.0 \\
\hline December & 133.8 & 61.90 & 154.7 & \\
\hline
\end{tabular}


International Journal of Advances in Scientific Research and Engineering (ijasre), Vol 6 (4), April -2020

The energy generation can be plotted according to the temperature variations as mentioned in the below figures.

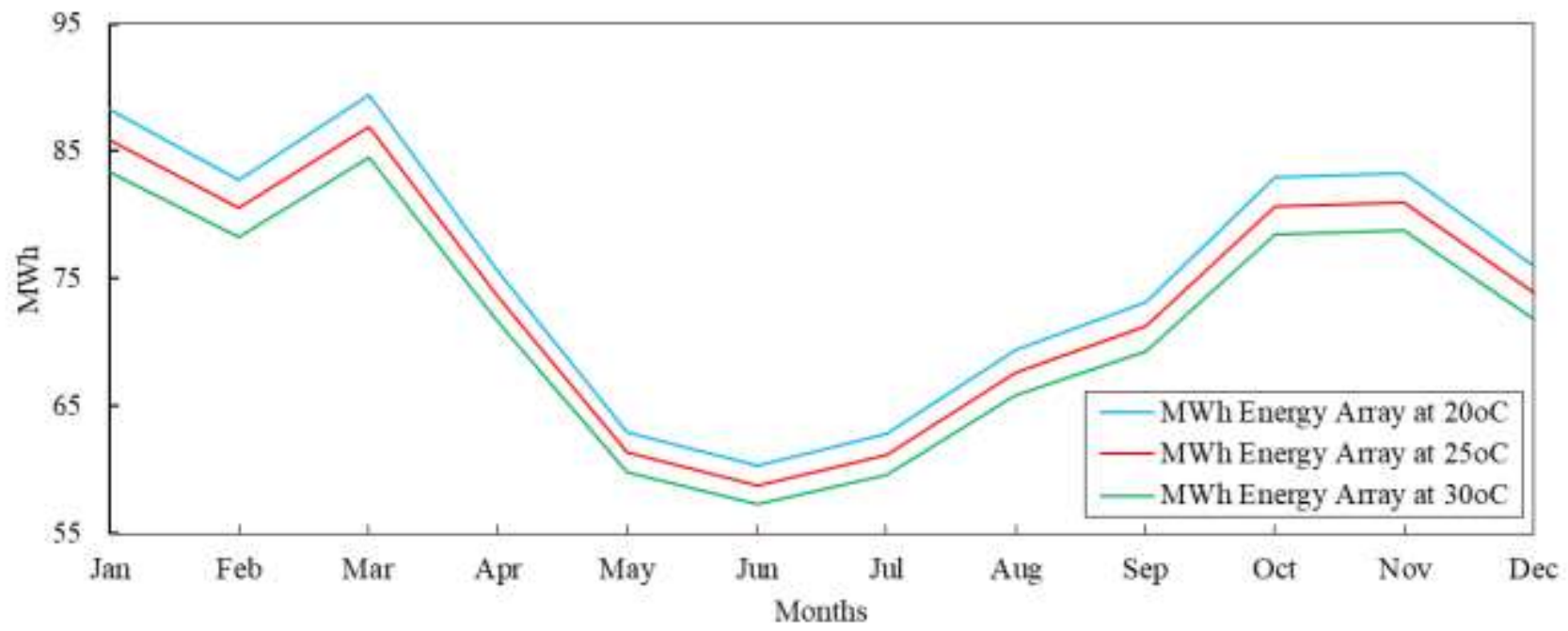

Fig. 4 MWh energy output from PV array under given temperature variations.

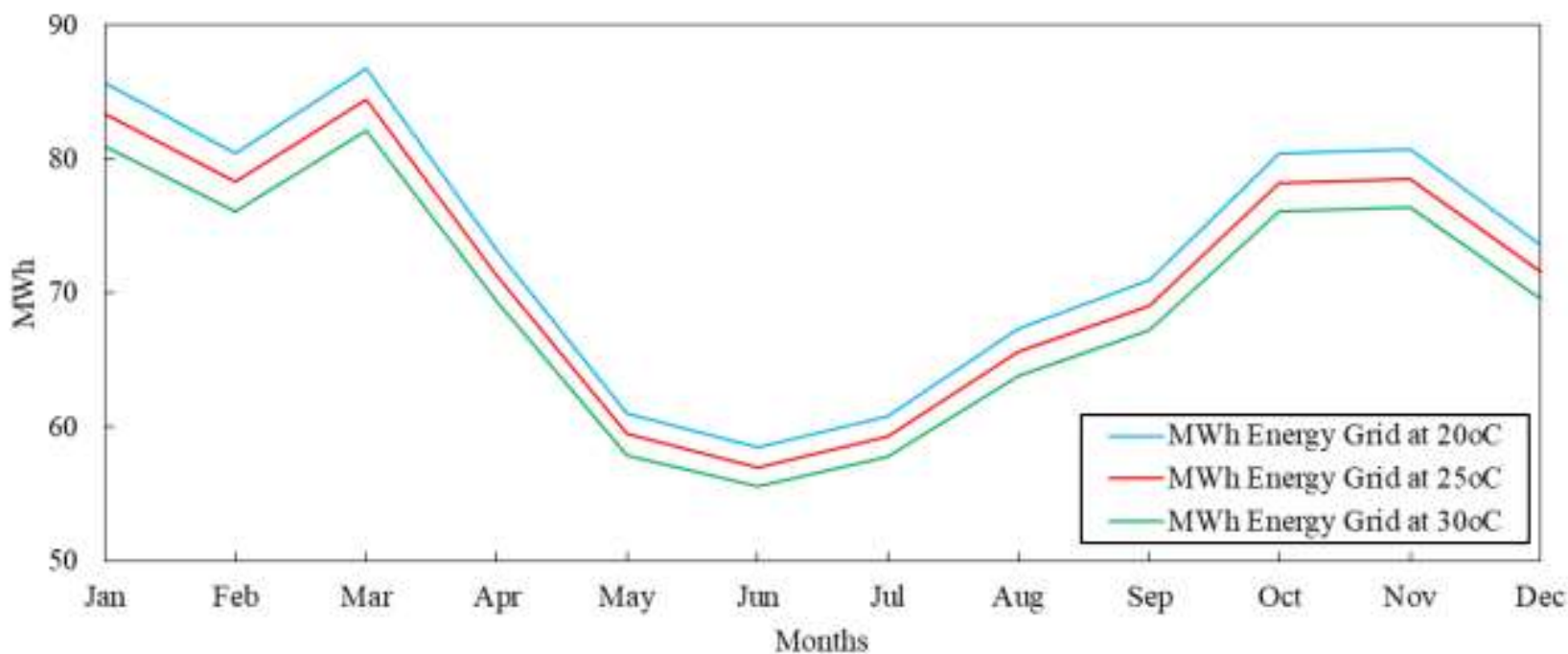

Fig. 5 MWh energy injected to grid under different temperature variations.

With these simulations, it can be identified that during temperatures of $20^{\circ}, 25^{\circ}$ and $30^{\circ}$, the annual production energy will be varied from $879.6 \mathrm{MWh} /$ year, $856.3 \mathrm{MWh} /$ year and $832.8 \mathrm{MWh} /$ year with the performance ratio of $82.90 \%, 80.71 \%$ and $78.49 \%$ respectively. With the loss diagrams obtained from the simulation results, the PV loss due to temperature will be $9.62 \%, 11.98 \%$ and $14.37 \%$ and the Ohmic wiring losses due to temperature will be $1.04 \%, 1.06 \%$ and $1.09 \%$ under 20,25 and 30 temperature levels respectively.

Apart from the power generation gain, the shading effect from PV panels will create more benefit towards the environment by reducing the water evaporation. With refer to the literature review, the evaporation reduction will be $0.32 \mathrm{~kg} / \mathrm{m}^{2}$ for one hour. Therefore, the designed system will be covering $28,200 \mathrm{~m}^{2}$ of water body which will be approximately save $9,235 \mathrm{~kg}$ of water every hour. If we assume that evaporation takes place primarily during the day in warmer months, the floating array could prevent the reservoir from losing about 23.6 million $\mathrm{kg}$ of water every year. 
International Journal of Advances in Scientific Research and Engineering (ijasre), Vol 6 (4), April -2020

\section{DISCUSSION}

The designed FPV system can be compared with table 3 mentioned in the literature review as mentioned in the below table.

Table. 8. Designed FPV system comparison with other methods

\begin{tabular}{|c|c|c|c|c|c|c|c|c|c|}
\hline $\begin{array}{l}\text { Research } \\
\text { Item }\end{array}$ & $\begin{array}{c}\text { Power } \\
\text { Gain }\end{array}$ & $\begin{array}{c}\text { Cost } \\
\text { reduce }\end{array}$ & $\begin{array}{c}\text { Power } \\
\text { Drop }\end{array}$ & $\begin{array}{c}\text { Cost } \\
\text { Increase }\end{array}$ & $\begin{array}{l}\mathrm{CO2} \\
\text { Save }\end{array}$ & $\begin{array}{l}\text { Water } \\
\text { Save }\end{array}$ & $\begin{array}{l}\text { Land } \\
\text { Save }\end{array}$ & $\begin{array}{c}\text { execution } \\
\text { ability }\end{array}$ & $\begin{array}{c}\text { Pros } \\
\text { weight }\end{array}$ \\
\hline [23] [24] & $x$ & $x$ & $\checkmark$ & $\checkmark$ & $\checkmark$ & $x$ & $x$ & $\checkmark$ & $2 / 6$ \\
\hline [12] & $\checkmark$ & $x$ & $x$ & $\checkmark$ & $\checkmark$ & $\checkmark$ & $\checkmark$ & $x$ & $4 / 6$ \\
\hline [14] & $\checkmark$ & $\checkmark$ & $x$ & $x$ & $\checkmark$ & $\checkmark$ & $\checkmark$ & $\checkmark$ & $6 / 6$ \\
\hline [9] & $\checkmark$ & $x$ & $x$ & $\checkmark$ & $\checkmark$ & $\checkmark$ & $\checkmark$ & $x$ & $4 / 6$ \\
\hline $\begin{array}{c}\text { Bi/FPV/ } \\
\text { Track }\end{array}$ & $\checkmark$ & $x$ & $x$ & $\checkmark$ & $\checkmark$ & $\checkmark$ & $\checkmark$ & $x$ & $4 / 6$ \\
\hline $\mathrm{Bi} / \mathrm{FPV}$ & $\checkmark$ & $x$ & $x$ & $\checkmark$ & $\checkmark$ & $\checkmark$ & $\checkmark$ & $\checkmark$ & $5 / 6$ \\
\hline $\begin{array}{c}\text { Mono- } \\
\text { facial } \\
\text { Ground PV }\end{array}$ & $x$ & $\checkmark$ & $\checkmark$ & $x$ & $\checkmark$ & $x$ & $x$ & $\checkmark$ & $3 / 6$ \\
\hline $\begin{array}{l}\text { Mono-track } \\
\text { Ground PV }\end{array}$ & $\checkmark$ & $x$ & $\checkmark$ & $\checkmark$ & $\checkmark$ & $x$ & $x$ & $\checkmark$ & $3 / 6$ \\
\hline $\begin{array}{c}\text { Designed } \\
\text { FPV } \\
\text { system }\end{array}$ & $\checkmark$ & $\checkmark$ & $x$ & $x$ & $\checkmark$ & $\checkmark$ & $\checkmark$ & $\checkmark$ & $6 / 6$ \\
\hline
\end{tabular}

According to the above table which was developed relatively compared to each PV power systems and marking a pros weighting factor from which highlighted, it is obtained that the designed FPV system and the research [14] has the best pros weight factor of $6 / 6$ and zero cons rate comparatively to each methods. Even though some proposed systems can obtain maximum power generation compared to author designed method, those systems cannot be implemented in large scale power systems since the limitation of the cost factor and the complexity of design and limitations. To observe the power gain of these systems, the author has compared the table 6 in the simulation chapter and created the table below,

Table. 9. Power generation comparison

\begin{tabular}{llll}
\hline \multicolumn{1}{c}{ Comparison items } & (7) Generation gain (\%) & \multicolumn{1}{c}{ Cost comparison } & \multicolumn{1}{c}{$\begin{array}{c}\text { Implementation } \\
\text { possibility }\end{array}$} \\
\hline Compare (1) with (7) & +12.0 Generation Gain & $10-15 \%$ less than (7) & (1) Possible (Widely used) \\
\hline Compare (2) with (7) & +10.25 Generation Gain & $10-15 \%$ less than (7) & (2) Possible (Widely used) \\
\hline Compare (3) with (7) & -2.54 Generation Drop & Almost similar & (3) Possible \\
\hline Compare (4) with (7) & -2.7 Generation Drop & $30-40 \%$ greater than (7) & (4) Not feasible [12] \\
\hline Compare (5) with (7) & -6.8 Generation Drop & $40-50 \%$ greater than (7) & (5) Not feasible \\
\hline Compare (6) with (7) & -3.4 Generation Drop & $5-10 \%$ greater than (7) & $\begin{array}{l}\text { (6) (7) possible (Latest } \\
\text { trend) }\end{array}$ \\
\hline Compare [14] with (7) & $+2 \%$ more gain & Almost similar & Possible \\
\hline
\end{tabular}

Therefore, it is clear that the designed mono-facial FPV system will be generated higher power compared to systems 1,2 and [14] and produce less power compared to 3,4,5 and 6, thus, the cost designed FPV system will be higher than 1 and 2 , while significantly less than 4,5 and 6. This will represent that the power generation will not be the only factor when designing a PV system but cost is one of the key factors.

\section{CONCLUSION}

This paper designed a FPV system with a capacity of 3MW power and used PVSyst software interface to perform the simulations. The FPV system used meteorological data from NASA and with simulations it was observed that FPV produced $10-12 \%$ more power generation compared to ground mounted PV and this is due to the temperature reduction of PV resultant of the water body. This effect from water cooling have reduced the PV loss, Ohmic wiring loss during 20 degrees Celsius significantly. The total array contains of $28,200 \mathrm{~m}^{2}$ of water area and it will prevent evaporation of 23.6 million $\mathrm{kg}$ of water every year, adding advance benefits towards the environment. With these results it can address the problem of negative impact on environment with PV energy, with solutions of, 
$\checkmark$ Does not use large acres of land for implementation and it saves land for agriculture / civilization purposes.

$\checkmark \quad \mathrm{No} \mathrm{CO}_{2}$ emission during power generation and improve the carbon footprint.

$\checkmark$ Save 23.6 Mn Kg of water every year by avoiding evaporation.

$\checkmark \quad$ The floating solar system will help to reduce Algae growth in the water by reducing the sun light exposure with the water area. Therefore, the water will be much cleaner, and it will be out of herbicides and algaecides and thus can be use it for drinking purposes.

And has achieved the below objectives,

$\checkmark \quad$ Design FPV system with less complexity and higher feasibility

$\checkmark$ Maximum power generation observed compared to other methods

$\checkmark$ Addition benefits towards environment compared to other PV methods
- Achieved

- Achieved

- Achieved

Therefore, FPV system has more advance benefits towards Environment, Energy and Economy perspectives.

\section{ACKNOWLEDGMENT}

I wish to record my deep sense of gratitude and profound thanks to my parents for their motivation and support given throughout this research, and thank all the researches who involved in renewable energy studies to make this world more greener and better place.

\section{CERTIFICATION STATEMENT}

I hereby declare that this thesis is my own original work and that, to the best of my knowledge and belief, it reproduces no material previously published or written, nor material that has been accepted for the award of any other degree or diploma, except due acknowledgement has been made in the text.

\section{REFERENCES}

[1] O. Sean, C. Clinton, P. Denholm, R. Margolis, and G. Heath, "Land-Use Requirements for Solar Power Plants in the United States," Natl. Renew. Energy Lab., 2013.

[2] A. Al Tarabsheh, M. Akmal, and M. Ghazal, "Series connected photovoltaic cells-Modelling and analysis," Sustain., vol. 9, no. 3, 2017.

[3] H. Bellia, R. Youcef, and M. Fatima, "A detailed modeling of photovoltaic module using MATLAB," NRIAG J. Astron. Geophys., vol. 3, no. 1, pp. 53-61, 2014.

[4] H. Tian, F. Mancilla-david, K. Ellis, E. Muljadi, and P. Jenkins, "A cell-to-module-to-array detailed model for photovoltaic panels," Sol. Energy, vol. 86, pp. 2695-2706, 2012.

[5] A. Sahu, N. Yadav, and K. Sudhakar, "Floating photovoltaic power plant: A review," vol. 66, pp. 815-824, 2016.

[6] J. Farfan and C. Breyer, "ScienceDirect ScienceDirect Combining Floating Solar Photovoltaic Power Plants and Hydropower Reservoirs : Virtual Battery of Power Great Global Potential Combining Floating Solar Photovoltaic Plants and The 15th International Symposium on District Heatin," Energy Procedia, vol. 155, pp. 403-411, 2018.

[7] "China built the world biggest floating solar project." [Online]. Available: https://mashable.com/2017/06/08/chinabiggest-floating-solar-project/\#Y371FMR4Okq6.

[8] M. Rosa-Clot and P. Rosa-Clot, "Support and method for increasing the efficiency of solar cells by immersion," PI2008A000088., 2008.

[9] R. Cazzaniga, M. Rosa-Clot, P. Rosa-Clot, and G. M. Tina, "Floating tracking cooling concentrating (FTCC) systems," Conf. Rec. IEEE Photovolt. Spec. Conf., pp. 514-519, 2012.

[10] K. Trapani and D. L. Millar, "Proposing offshore photovoltaic (PV) technology to the energy mix of the Maltese islands," Energy Convers. Manag., vol. 67, pp. 18-26, 2013. 
International Journal of Advances in Scientific Research and Engineering (ijasre), Vol 6 (4), April -2020

[11] C. Ferrer-Gisbert, J. J. Ferrán-Gozálvez, M. Redón-Santafé, P. Ferrer-Gisbert, F. J. Sánchez-Romero, and J. B. Torregrosa-Soler, "A new photovoltaic floating cover system for water reservoirs," Renew. Energy, vol. 60, pp. 63-70, 2013.

[12] Y. K. Choi and Y. G. Lee, "A study on development of rotary structure for tracking-type floating photovoltaic system," Int. J. Precis. Eng. Manuf., vol. 15, no. 11, pp. 2453-2460, 2014.

[13] C. Solanki, G. Nagababu, and S. S. Kachhwaha, "Assessment of offshore solar energy along the coast of India," Energy Procedia, vol. 138, pp. 530-535, 2017.

[14] M. Rosa-Clot, G. M. Tina, and S. Nizetic, "Floating photovoltaic plants and wastewater basins: An Australian project," Energy Procedia, vol. 134, pp. 664-674, 2017.

[15] R. Cazzaniga, M. Cicu, M. Rosa-Clot, P. Rosa-Clot, G. M. Tina, and C. Ventura, "Compressed air energy storage integrated with floating photovoltaic plant," J. Energy Storage, vol. 13, pp. 48-57, 2017.

[16] C. Study, S. Kei, S. E. Moluccas, A. F. Tofani, I. Garniwa, and F. R. Fajry, "Techno-Economic Analysis of Sea Floating PV / Diesel Hybrid Power Plant with Battery Arrangement Scheme for Residential Load at Remote Area in Indonesia," 2018 Int. Conf. Electr. Eng. Comput. Sci., vol. 17, pp. 243-246.

[17] L. E. Teixeira, J. Caux, A. Beluco, I. Bertoldo, J. A. S. Louzada, and R. C. Eifler, "Feasibility Study of a Hydro PV Hybrid System Operating at a Dam for Water Supply in Southern Brazil," J. Power Energy Eng., vol. 03, no. 09, pp. 70$83,2015$.

[18] Ciel \& Terre, "Floating solar site selection," 2017.

[19] A. D. Bank, "Initial Environmental and Social Examination Report - Annex A-2 Proposed Loan and Administration of Loans Da Nhim - Ham Thuan - Da Mi Hydro Power Joint Stock Company Floating Solar Energy Project ( Viet Nam )," no. October, 2018.

[20] Longi Solar, "Longi solar LR6-72PH 360-380M," 2017. [Online]. Available: https://en.longisolar.com/Home/Products/module/id/44.html.

[21] S. Kurtz et al., "Photovoltaic Module Qualification Plus Testing Photovoltaic Module Qualification Plus Testing," no. December, 2013.

[22] S. Kim, "Design and Construction of 1 MW Class Floating PV Generation Structural System Using FRP Members," 2017.

[23] C. E. Valdivia, C. T. Li, A. Russell, J. E. Haysom, R. Li, and D. Lekx, "Bifacial Photovoltaic module energy Yield calculation and analysis,” 2017 IEEE 44th Photovolt. Spec. Conf. PVSC 2017, pp. 1-4, 2017.

[24] N. H. Zaini, M. Z. Ab Kadir, M. Izadi, N. I. Ahmad, M. A. M. Radzi, and N. Azis, “The effect of temperature on a monocrystalline solar PV panel,” 2015 IEEE Conf. Energy Conversion, CENCON 2015, pp. 249-253, 2015. 